still far from depleted, and much has remained for inclusion here of interest and of value for the student of magic, ritual and belief. Especially intercsting are the extracts from the records of early Catholic missionaries, whether they deal with Tibet, Indo-China, or the Chinese Empire. Among the Tibetan, Chinese and Japanese extracts, especially valuable are those which include some of W. W. Rockhill's less accessible notes; while the records of the Korean and Siberian peoples might well serve as a starting point for a study of 'possession' and shamanism. The extracts from John Richardson's travels in Persia, which deal with a little-known side of Persian traditional belief, the angelic associations of the months, are of noteworthy interest for the study of the developments of magical thought in the East.
It was, perhaps, inevitable that the European material should scarcely lend. itself to the treatment, which has proved so favourable in dealing with the records of more primitive peoples. The literature is both too familiar and too extensive. Hence these extracts, by contrast, must seem scrappy. Nevertheless, there is much of interest and value, among the more notable being early accounts of the northern form of witcheraft in Lapland and Scandinavia, with the southern European vampires and witches in contrast, and of the survivals in Central Europe of the worship of pagan deities.

The work of editing these extracts has been carried out by Mr. Downie once more with meticulous care, and he has enhanced their utility by a series of illustrative maps and a comprehensive index.

\title{
ARTIFICIAL RADIOACTIVITY
}

\section{(I) Atomes, radioactivité, transmutations}

Par Maurice de Broglie. (Bibliothèque de Philosophio scientifique.) Pp. 270. (Paris: Ernest Flammarion, 1939.) 22 francs.

(2) Künstliche Radioaktivität und ihre kernphysikalischen Grundlagen

Von Prof. Dr. W. Hanle. Pp. viii $+114+7$ plates. (Jena: Gustar Fischer, 1939.) 12 gold marks.

\section{(3) Künstliche Radioaktivität : Experimentelle} Ergebnisse

Von Dr. Kurt Diebner und Dr. Eberhard Grass. mann. Pp. xi+87. (Leipzig: S. Hirzel, 1939.) 12 gold marks.

(1) THE first of these books represents one of the most pleasing accounts of the present position of nuclear physics that the reviewer has read. It gives a most up-to-date description of the neutron and its properties, of natural and artificial radioactivity and of the new chemistry of the nucleus, couched in very clear language and eminently suitable for the general reader. At the same time, all important features of modern work in these branches of physics are covered in an extraordinarily complete manner. The work can confidently. be recommended to all students, particularly those who wish to improve their knowledge of French.

(2) The second book is also meant for the general reader, but it is rather more restricted in its range of subject-matter. It gives a brief introduction to the fundamental conceptions of the structure of the atom, a description of the elemen. tary particles of modern physics and their role in nuclear structure, and a short but very beautifully illustrated account of the experimental methods used in experiments on nuclear transformations. It is a sad reflection that in recent years Germany has taken so little part in the development of these methods. The book also describes in some detail the various types of nuclear changer and the methods of producing artificial radioactivity, a special section being devoted to $\gamma$-radiation. It concludes with a few remarks on possible applications of the results of nuclear physics experiments to chemistry, biology, medicine and technology, and contains a striking series of coloured graphs illustrative of the transformations of natural and artificial radioactive elements.

(3) The third book is really a very valuable set of physical tables. In it are set forth the data on artificial radioactivity published up to September 1938. There is no attempt at describing the methods of experiment or of analysing the results in a critical manner. The work is intended as a reference book for the research worker and the teacher who wishes to know whether a particular nuclear reaction has been studied, and so on. A list of nearly 350 references is giren, and in addition to a full analysis of the separate nuclear reactions for each element under such headings as artificial radioactivity produced by $\alpha$-rays, artificial radioactivity produced by protons, etc., the data is also set forth in tabular form. A very large coloured diagram or graph of the stable and radioactive isotopes is included.

L. F. BAtes. 